\title{
アナモックス反応による化学工場排水中の窒素処理実証
}

\author{
木 村 裕 哉1), 凤 \\ 井 坂 和 -11

\section{Pilot-Scale Tests of Nitrogen Removal from Ammonium Plant Effluent Using Anaerobic Ammonium Oxidation System}

\section{Yuya KIMURA ${ }^{1), ~ a n d ~ K a z u i c h i ~ I S A K A ~}{ }^{1)}$}

1) Infrastructure Systems Company, Hitachi, Ltd., 537 Kami-Hongo, Matsudo, Chiba 271-0064, Japan

\begin{abstract}
Pilot-scale tests were carried out for nitrogen removal from ammonium plant effluent using gel carriers on which anaerobic ammonium oxidation (anammox) sludge was immobilized. The nitrogen removal system was equipped with an anammox vessel of $5 \mathrm{~m}^{3}$ volume and the pretreatment processes were carried out for continuous feeding tests. The nitrogen removal in the anammox vessel could be started up within approximately 2 months of acclimation using ammonia synthetic plant effluent (ammonia wastewater) at $30^{\circ} \mathrm{C}$. After that, stable nitrogen removal in the anammox vessel was confirmed at $16.1^{\circ} \mathrm{C}$ even though the influent was changed to another kind of wastewater based on urea. Moreover, nitrogen removal in the anammox vessel reached the designated denitrification rate within 3 days at $30^{\circ} \mathrm{C}$ after influent wastewater was returned to the original ammonia wastewater. Finally, the anammox vessel was operated using the ammonia wastewater at a low water temperature. The nitrogen conversion rate was stably observed $1.9 \mathrm{~kg}-$ $\mathrm{N} \cdot \mathrm{m}^{3} \cdot \mathrm{d}^{-1}$ at $17.1^{\circ} \mathrm{C}$. These results strongly suggest that this nitrogen removal system using anammox gel carrier can be applied to nitrogen removal from industrial effluent under low water temperature.
\end{abstract}

Keywords: Ammonium; Immobilization; Anaerobic ammonium oxidation; Biological wastewater treatment; Chemical plant effluent

\section{1.はじめに}

産業排水や下水などを起因とする窒素の流出により, 内湾，湖沼など閉鎖系水域において，富栄養化が問題と なっている。窒素を排出する事業場に対する排水規制は 年々強化されており，2014 年には第 7 次総量規制基準 が適用された ${ }^{1)}$ 。排水中の窒素の除去技術は, 生物学的 な硝化反応と脱窒反応を組み合わせた硝化・脱窒法が有 効とされており，幅広い排水に適用されている。この硝 化·脱窒法は排水中のアンモニアを硝酸まで硝化した後, 排水中の有機物質量が不足する場合にはメタノール等の 有機物を添加し, 硝酸を窒素ガスに転換して脱窒処理す る。しかしながら，アンモニアが高濃度に含まれる排水 を処理する場合, 硝化反応に伴う多量の酸素供給や, 脱 窒反応のためのメタノール等の薬剂供給が必要となるな どの課題を有する。また, 処理速度が遅いため, 反応槽 の設置スペースが広大となることも問題である ${ }^{2,3)}$

これらの課題を解決できる方法として, 嫌気性アンモ ニア酸化（anaerobic ammonium oxidation; 以下, アナモッ クス）反応の活用が注目されている。アナモックス反応 は, 1990 年代に発見された生化学反応であり, 独立栄
養性のアナモックス菌がその反応を担っている ${ }^{4 \sim 6)}$ 。実 験的に得られたアナモックス反応の化学量論式 ${ }^{7)}$ 次式 (1)に示す。アナモックス反応では, アンモニアとその約 1.3 倍量の亜硝酸が反応し, 有機物を必要とせず脱窒す る。このアナモックス反応をアンモニアが主成分ある窒 素排水の処理に適用させる場合, 硝化菌によりアンモニ アの約半量を亜硝酸に酸化する亜硝酸型硝化工程を前段 に組み合わせた排水処理システム（以下，アナモックス 処理システム）となる。アナモックス反応は排水中のア ンモニアの約半量を直接窒素ガスへ変換できるため, 従 来の硝化 ·脱窒法に比べ, 硝化反応に必要な酸素供給量 を大幅に削減し, かつ脱窒反応で必要な有機物添加量を 削減できるとともに，それに伴う污泥発生量の削減がで きる ${ }^{8)}$ 。さらに従来法より窒素ガスへ変換する処理速度 が速いため, 反応槽を小さくできることから, 省エネル ギーで省スペース型の排水処理技術となり得る ${ }^{9,10)}$ 。特 にアンモニア濃度が高く, C/N 比の低い排水に適用する ことで大きなコストメリットが得られる。

$$
\begin{aligned}
& \mathrm{NH}_{4}^{+}+1.32 \mathrm{NO}_{2}^{-}+0.066 \mathrm{HCO}_{3}^{-}+0.13 \mathrm{H}^{+} \rightarrow \\
& 1.02 \mathrm{~N}_{2}+0.26 \mathrm{NO}_{3}^{-}+0.066 \mathrm{CH}_{2} \mathrm{O}_{0.5} \mathrm{~N}_{0.15}+2.03 \mathrm{H}_{2} \mathrm{O} \cdots(1)
\end{aligned}
$$

1）株式会社日立製作所インフラシステム社 テ 271-0064 千葉県松戸市上本郷 537

凤 連絡先 : yuuya.kimura.kv@hitachi.com 
このアナモックス菌の至適温度は $37^{\circ} \mathrm{C}$ 付近の高水温 とされており ${ }^{11,12)}$, 多くの排水処理試験や集積培養など は高水温条件で検討されていた ${ }^{13,14)}$ 。対象排水は主に消 化污泥を脱水した後の分離液（以下，消化污泥脱水ろ 液) などの $25 \sim 35^{\circ} \mathrm{C}$ で排出される発酵系排水 ${ }^{15)}$ であり, 実用化されたシステムにおいても消化污泥脱水ろ液が多 数を占める ${ }^{16)}$ 。筆者らはこれまで消化污泥脱水ろ液を対 象に，包括固定化技術によりアナモックス菌を担体内に 固定化したアナモックス処理システムの実証試験を実施 し, 安定的な窒素処理性能を報告している ${ }^{17,18)}$ 。

一方でアンモニア濃度が高い排水は発酵系排水とは限 らず，無機薬品製造業，貴金属製造業など様々な産業排 水から排出され，このアナモックス処理システムも従来 の硝化 · 脱窒法と同様に, 産業排水に適用拡大できるこ とが実証できれば，その普及が十分に期待できる。

しかしながら, アナモックス処理システムにおいて発 酵系でない産業排水を使用し，処理性能の立上げや水温 や水質の変動に対する安定性を評価した事例は極めて少 ない ${ }^{19)}$ 。アナモックス処理システムを産業排水へ適用す る大きな課題としては, 発酵系排水とは異なり水温が変 動することが挙げられる。特に，冬季などでは排水温度 が $15^{\circ} \mathrm{C}$ 程度に低下し, 低水温条件下で安定処理が可能 なシステムが必要である。また工場での生産内容の変更 や定期修繥などにより，排水種類が大きく変動すること がある。これに伴い, 水温の急激な変動も想定され, 水 質や水温の変動に対応でき, かつ低水温でも安定処理が 可能な排水処理システムが望まれる。さらにメタノール 等の化学物質が共存する可能性があり, それらに対応し たシステム構築が求められる。

そこで本研究では, 包括固定化担体を用いたアナモッ クス処理システムを産業排水に適用することを目的に, 共存化学物質にも対応できる排水処理システムの構築を 行い, 化学工場系の実排水を用いた実証試験を実施した。 そして産業排水の適用で必要とされる運転要素として, 実排水での処理性能の立上げ, 工場排水の水質変動およ び $15 \sim 30^{\circ} \mathrm{C}$ の水温変動および $15 \sim 20^{\circ} \mathrm{C}$ の低水温条件 での窒素処理性能の安定性評価について，アナモックス 槽 $5 \mathrm{~m}^{3}$ 規模の実証試験装置を用いて検討を行った。

\section{2. 方法}

\section{1 供試排水}

表 1 に示す A 社化学工場から排出される 2 種類の実 排水を実証試験に用いた。立上げおよび水温変動試験で は, アンモニアを合成する過程で排出され, アンモニ アを主体成分とする高水温のアンモニア製造排水を用 いた。これはアンモニア濃度が約 $700 \mathrm{mg}-\mathrm{N} \cdot \mathrm{L}^{-1}$ であり, また約 $100 \mathrm{mg} \cdot \mathrm{L}^{-1}$ のメタノールを含有する $\mathrm{C} / \mathrm{N}$ 比の低

表 1 実排水組成

\begin{tabular}{lcc}
\hline 分析項目 & アンモニア製造排水 & 尿素排水 (希釈後) \\
\hline 全窒素濃度 $\left(\mathrm{mg} \cdot \mathrm{L}^{-1}\right)$ & $725(580 \sim 892)$ & $997(543 \sim 1238)$ \\
アンモニア濃度 $\left(\mathrm{mg}-\mathrm{N} \cdot \mathrm{L}^{-1}\right)$ & $687(579 \sim 784)$ & $349(151 \sim 468)$ \\
D0C濃度 $\left(\mathrm{mg} \cdot \mathrm{L}^{-1}\right)$ & $37(7 \sim 198)$ & $277(103 \sim 370)$ \\
メタノール濃度 $\left(\mathrm{mg} \cdot \mathrm{L}^{-1}\right)$ & $97(52 \sim 125)$ & $92(56 \sim 128 ;$ 添加 $)$ \\
アルカリ度 $\left(\mathrm{mg} \cdot \mathrm{L}^{-1}\right)$ & $2,700(2,600 \sim 2,900)$ & - \\
無機峞素濃度 $\left(\mathrm{mg} \cdot \mathrm{L}^{-1}\right)$ & $552(450 \sim 655)$ & $155(92 \sim 206)$
\end{tabular}

い排水であった。排水の水温は約 $60^{\circ} \mathrm{C}$ と高温であるた

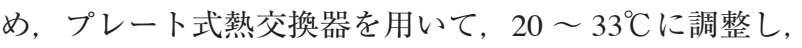
これを原水として試験に用いた。

また A 社化学工場の運転上，一時的にアンモニア製 造排水の排出が停止する期間があり，この期間は本シス テムの維持および窒素成分の一部処理を目的として, 尿 素を合成する過程で排出され，尿素成分を主体とする常 温の尿素排水を試験に用いた。尿素排水は全窒素濃度が 約 $27,000 \mathrm{mg} \cdot \mathrm{L}^{-1}$ 以上含有するため, 工業用水を用いて 約 20 倍希釈し, これを原水とし試験に用いた。なお全 窒素（T-N）の $30 \%$ 程度がアンモニア態窒素であり，こ のアンモニアを処理対象とした。

\section{2 供試污泥および供試担体}

アナモックス担体は集積培養したアナモックス污泥 を, 脱窒担体, BOD 酸化担体および硝化担体は下水処 理場から採取した活性污泥を基本に，ポリエチレングリ コール（PEG）系のゲルで包括固定化し， $3 \mathrm{~mm}$ 角の立 方体に成型したものを用いた ${ }^{10,20)}$ 。アナモックス担体中 にはアナモックス污泥を $0.2 \%\left(2,000 \mathrm{mg}-\mathrm{SS} \cdot \mathrm{L}^{-1}\right)$ 投入 した。脱窒担体, BOD 酸化担体および硝化担体中の活 性污泥量は $2 \%\left(20,000 \mathrm{mg}-\mathrm{SS} \cdot \mathrm{L}^{-1}\right)$ とした。

\section{3 試験装置}

\section{3.1 システムフロー}

実証試験装置の処理フローを図 1 に示す。本研究で使 用するアンモニア製造排水はアンモニア濃度約 $700 \mathrm{mg}$ $\mathrm{N} \cdot \mathrm{L}^{-1}$ であり, 有機物質としてメタノールが $100 \mathrm{mg} \cdot \mathrm{L}^{-1}$ 程度含まれた。メタノールは硝化槽に流入すると硝化阻 害が生じ, 硝化活性は大きく低下するだけでなく ${ }^{21)}, \quad ア$ ナモックス反応を特異的に阻害することが報告されてい る ${ }^{22)}$ 。また一旦メタノールによりアナモックス反応が阻 害されると, 不可逆的な阻害となることから ${ }^{23)}$, その影 響は重大である。メタノールなどの影響なく，アナモッ クス反応による窒素処理を安定的に行うためには, 亜硝 酸型硝化槽と特にアナモックス槽ヘメタノールを流入さ せない対策が必要であった。そこで窒素処理工程の前段 に脱窒槽およびBOD 酸化槽を設置した。亜硝酸を含む 亜硝酸型硝化槽からの硝化処理水を脱窒槽に循環し, こ の脱窒処理過程でメタノールを消費させる。BOD 酸化槽 では脱窒槽で残留するメタノールを好気的に酸化分解さ せる。また少量のメ夕ノールであれば亜硝酸型硝化槽に おいても, 好気的な酸化分解が期待できる。これらのこ とからアナモックス槽の前段に, 脱窒槽と BOD 酸化槽 および亜硝酸型硝化槽の三重のメタノール対策を施した 排水処理フローとなる。また，本システムは，すべての 処理水槽は包括固定化技術により固定化された担体を用 い，返送污泥を使用しないシステムとした。

\section{3.2 前脱窒槽}

前脱窒槽の反応容積は $2 \mathrm{~m}^{3}$ とし, 脱窒担体を $0.2 \mathrm{~m}^{3}$ 投入した（担体充填率 $10 \%$ ）。前脱窒槽には原水および

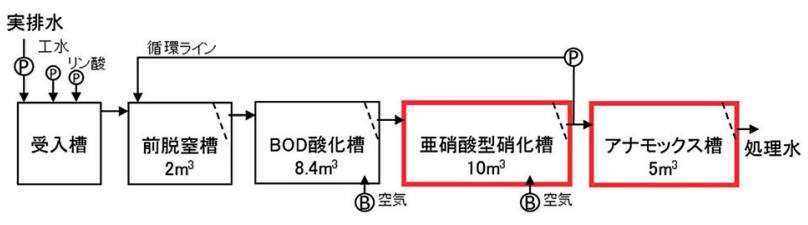

図1 実証試験装置の処理フロー 
亜硝酸型硝化槽からの循環水を通水し, 原水中の有機物 と循環水中の亜硝酸を従属栄養性の脱窒反応により消費 させた。また槽内は擋拌機を用いて緩速擋拌を行った。

\subsection{BOD 酸化槽}

BOD 酸化槽の反応容積は $8.4 \mathrm{~m}^{3}$ とし, BOD 担体を 0.42 $\mathrm{m}^{3}$ 投入した（担体充填率 $5 \%$ ）。原水もしくは前脱窒槽 の処理水を通水し, 残留する有機物を空気曝気により酸 化分解処理した。

\section{3.4 亜硝酸型硝化槽}

亜硝酸型硝化槽の反応容積は $10 \mathrm{~m}^{3}$ とし, 硝化担体を $2 \mathrm{~m}^{3}$ 投入した（担体充填率 $20 \%$ ）。有機物を除去した BOD 酸化槽の処理水（以下, BOD 酸化処理水）を通水 し，空気曝気によりアンモニアの一部を亜硝酸に酸化さ せた。亜硝酸型硝化槽の全窒素濃度とアンモニア性窒素 濃度をモニタリングし, 全窒素濃度とアンモニア性窒素 濃度の差を亜硝酸性窒素濃度とみなした。そして処理水 中のアンモニア性窒素濃度に対する亜硝酸性窒素濃度の 割合 (以下, 硝化率) を後述の式(2)で求め, 硝化率をア ナモックス反応に適する 50 〜 $60 \%$ に調整した。この調 整には，算出された硝化率と亜硝酸型硝化槽に設置した DO 濃度計の DO 濃度を用い, 以下に示す Isaka ら ${ }^{17)}$ の 制御方法を基本に曝気量を変動させることで制御した。 硝化率が $50 \sim 60 \%$ の場合, DO 濃度が $3 \mathrm{mg} \cdot \mathrm{L}^{-1}$ となる ように曝気量を制御した。また硝化率が $50 \%$ に満たな いときは, 設定 DO 濃度を $4 \mathrm{mg} \cdot \mathrm{L}^{-1}$ にし, 硝化率を増 加させ, 硝化率が $60 \%$ を超える場合は, 設定 DO 濃度 を $2 \mathrm{mg} \cdot \mathrm{L}^{-1}$ にし, 硝化率を減少させた。 $\mathrm{pH}$ は $25 \%$ 水酸 化ナトリウム溶液を用いて $\mathrm{pH} 7.5$ に調整した。

\subsection{5 アナモックス槽}

アナモックス槽の反応容積は $5 \mathrm{~m}^{3}$ とし, アナモック ス担体を $1 \mathrm{~m}^{3}$ 投入した（担体充填率 $20 \%$ )。アンモニア と亜硝酸を含む硝化処理水を通水し, アナモックス反応 により脱窒させた。 $\mathrm{pH}$ は $25 \%$ 硫酸溶液を用いて $\mathrm{pH} 7.5$ に調整した。また槽内は擋拌機を用いて緩速擋拌を行っ た。

\section{4 立上げ試験方法}

アンモニア製造排水を原水とし, 水温 $30^{\circ} \mathrm{C}$ に調整し た。受入槽に原水と栄養源として $42.5 \%$ リン酸溶液を 5 $\mathrm{mg}-\mathrm{P} \cdot \mathrm{L}^{-1}$ となるように添加し, 連続的に前脱窒槽もし くは BOD 酸化槽に流入水量 $30 \mathrm{~m}^{3} \cdot \mathrm{d}^{-1}$ で流入させた。性 能立上げは(1) BOD 酸化槽, (2)亜硝酸型硝化槽, (3)アナ モックス槽, (4)前脱窒槽と順に行った。なお包括固定化 担体を用いた性能の立上げは, 担体内での各性能を持つ 細菌の増殖を想定し, 所定の処理速度や処理性能を得る までの工程としている ${ }^{10)}$ 。

(1) BOD 酸化槽：原水を前脱窒槽に通過させず, BOD 酸化槽へ直接流入させ, 原水中の有機物処理を行った。 空気曝気により好気処理を行い, 本試験での立上げ完 了の基準としては処理水中のメタノール濃度が $1 \mathrm{mg} \cdot \mathrm{L}^{-1}$ 以下とした。なお立上げ期間中は BOD 酸化処理水を亜 硝酸型硝化槽以降へ流さず，槽外に排出させた。

(2) 亜硝酸型硝化槽：BOD 酸化槽の立上げ後の BOD 酸化処理水を利用し, 覀硝酸型硝化性能の立上げを行っ た。立上げ完了の基準は硝化処理水中の硝化率が $50 \%$ 以上とした。立上げ期間中は硝化処理水をアナモックス 槽へ流さず，槽外に排出させた。
(3) アナモックス槽：亜硝酸型硝化槽では硝化率 50 〜 $60 \%$ とするため, 硝化処理水には亜硝酸濃度が $300 \mathrm{mg}$ $\mathrm{N} \cdot \mathrm{L}^{-1}$ 以上含まれる。アナモックス菌は高濃度の亜硝酸 により増殖が阻害され ${ }^{24)}$, 特に立上げ初期はその影響は 著しいと考えたため, 表 2 に示す 8 条件で段階的にアナ モックス槽の窒素除去性能を立上げた。フェーズ 1,2 で は別に設けたアナモックス原水槽に, 硝化処理水と希釈 水とした工業用水をそれぞれ所定の流量で流入させた。 アナモックス原水槽は脱気および擋拌のため, 窒素ガス 曝気を行った後, アナモックス槽に流入させた。フェー ズ 3 以降はアナモックス原水槽を利用せず, 硝化処理水 をアナモックス槽に直接流入させた。アナモックス槽の 窒素除去率が $75 \%$ 以上を示した時点で, 次のフェーズに 引き上げ，本試験での最終フェーズ 8 における立上げ完 了基準は窒素除去速度 $3.0 \mathrm{~kg}-\mathrm{N} \cdot \mathrm{m}^{3} \cdot \mathrm{d}^{-1}$ とした。

(4) 前脱窒槽: アナモックス槽の立上げ後に, 前脱 窒槽に原水および硝化処理水をそれぞれ $30 \mathrm{~m}^{3} \cdot \mathrm{d}^{-1}, 4$ $\mathrm{m}^{3} \cdot \mathrm{d}^{-1}$ の条件で流入させた。立上げ完了の基準は亜硝酸 と溶解性有機炭素 (DOC) 濃度が同時に減少し, 処理水 中の亜硝酸濃度が $10 \mathrm{mg} \cdot \mathrm{L}^{-1}$ 以下とした。なおここでは 脱窒反応に寄与しないアンモニアは評価対象外とした。

\section{5 尿素排水を用いた低水温条件での実証試験方法}

高水温のアンモニア製造排水が停止する期間は, 常温 で排出される尿素排水を原水として運転を行った。当該 期間は冬季であったため, 低水温条件での実証試験と なった。この尿素排水に, 栄養源として $42.5 \%$ リ酸溶 液を $5 \mathrm{mg}-\mathrm{P} \cdot \mathrm{L}^{-1}$ となるように受入槽に添加した。また 尿素排水にはメタノールが含まれていないため, 有機物 除去工程の性能を維持させる目的で, メタノール濃度が $100 \mathrm{mg} \cdot \mathrm{L}^{-1}$ となるように $15 \%$ のメタノール溶液を受入 槽に添加した。水温低下を考慮して流入水量 $15 \mathrm{~m}^{3} \cdot \mathrm{d}^{-1}$ に低下させて前脱窒槽に流入させた。また亜硝酸型硝 化槽からの循環水量は $2 \mathrm{~m}^{3} \cdot \mathrm{d}^{-1}$ の条件とした。なお, 装 置の特性上, 水温が低下する傾向が観られたため, 亜硝 酸型硝化槽とアナモックス槽の水温はヒータを用いて $15^{\circ} \mathrm{C}$ 以下にならないよう維持した。

本試験期間中は, 窒素除去工程である亜硝酸型硝化槽 およびアナモックス槽の窒素処理性能のみを評価した。 また窒素処理性能の評価は, 尿素の分解過程で生成した 無機性窒素（アンモニア, 亜硝酸および硝酸）のみを対 象とし，アナモックス反応で処理できない尿素そのもの は対象外とした。なお亜硝酸型硝化槽の設定硝化率は

\begin{tabular}{|c|c|c|}
\hline フェーズ & 工水希釈倍 & 総流入量 $\left(\mathrm{m}^{3} \cdot \mathrm{d}^{-1}\right)$ \\
\hline 1 & 5倍希䣋 & 5 \\
\hline 2 & 2倍希䣋 & 5 \\
\hline 3 & 希釈なし & 5 \\
\hline 4 & 希釈なし & 7.5 \\
\hline 5 & 希釈なし & 10 \\
\hline 6 & 希釈なし & 15 \\
\hline 7 & 希釈なし & 20 \\
\hline 8 & 希釈なし & 30 \\
\hline
\end{tabular}


$50 \%$ 以上とした。また本試験でのアナモックス槽の設定

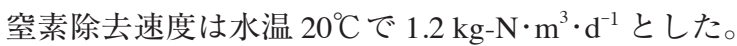

\section{6 水温変動条件での実証試験方法}

\section{6.1 原水切り替えによる水温変動試験}

高水温のアンモニア製造排水の再排出に合わせ，原水 を尿素排水からアンモニア製造排水に切替えた。受入槽 には水温を $33^{\circ} \mathrm{C}$ に調整したアンモニア製造排水と栄養 源として $42.5 \%$ リン酸溶液を $5 \mathrm{mg}-\mathrm{P} \cdot \mathrm{L}^{-1}$ となるように 添加し, 流入水量を $33 \mathrm{~m}^{3} \cdot \mathrm{d}^{-1}$ の条件に上昇させた。循 環水量は, $4 \mathrm{~m}^{3} \cdot \mathrm{d}^{-1}$ の条件で前脱窒槽に返送し，水温お よび窒素負荷を上昇させたときの亜硝酸型硝化槽および アナモックス槽の窒素処理性能を評価した。なお亜硝酸 型硝化槽の設定硝化率は 50 ～ $60 \%$ とし，水温 $30^{\circ} \mathrm{C}$ で のアナモックス槽の設定窒素除去速度は $3.0 \mathrm{~kg}-\mathrm{N} \cdot \mathrm{m}^{3} \cdot \mathrm{d}^{-1}$ とした。

2.6.2 アンモニア製造排水での水温変動試験

アンモニア製造排水での水温変動の影響を評価する ため, 原水の水温を $20 \sim 25^{\circ} \mathrm{C}$ に調整し, 流入水量 15 $\mathrm{m}^{3} \cdot \mathrm{d}^{-1}$, 循環水量 $2 \mathrm{~m}^{3} \cdot \mathrm{d}^{-1}$ の条件で, 前脱窒槽に通水した。 さらに原水水温を $15 \sim 20^{\circ} \mathrm{C}$ に調整し, 低水温条件での 亜硝酸型硝化槽およびアナモックス槽の窒素処理性能を 評価した。なお亜硝酸型硝化槽の設定硝化率は 50 \% 以 上とし, 水温 $20^{\circ} \mathrm{C}$ でのアナモックス槽の設定窒素除去 速度は $1.2 \mathrm{~kg}-\mathrm{N} \cdot \mathrm{m}^{3} \cdot \mathrm{d}^{-1}$ とした。

\section{7 分析方法および評価方法}

\subsection{1 分析方法}

各槽への流入水および処理水中の窒素濃度または有機 物濃度を定期的に測定した。サンプルはメンブレンフィ ルタ（孔径 $0.45 \mu \mathrm{m} ）$ を用いてろ過した後, 分析を行っ た。アンモニアはインドフェノール青吸光光度法を用い た。また亜硝酸と硝酸については, イオンクロマトグラ フ（ICS-1500, Dionex）を用いて分析した。有機物濃度 の指標とした DOC 濃度は全有機体炭素計（TOC-V, 島津 製作所）を用いて，メタノール濃度はガスクロマトグラ フ質量分析計（GCMS-QP2010, 島津製作所）を用いて分 析した。

\subsection{2 評価方法}

亜硝酸型硝化槽の処理性能の評価では, 硝化率 （NE：\%）を指標とし，次式(2)に示すように，硝化処理 水中のアンモニア濃度 $\left(\mathrm{C}_{\mathrm{NH} 4, \mathrm{no}}: \mathrm{mg}-\mathrm{N} \cdot \mathrm{L}^{-1}\right)$ と亜硝酸濃度 $\left(\mathrm{C}_{\mathrm{NO} 2, \mathrm{no}}: \mathrm{mg}-\mathrm{N} \cdot \mathrm{L}^{-1}\right)$ の和に対する硝化処理水中の亜硝酸 濃度の割合から求めた。

$$
N E=\frac{C_{N O 2, n o}}{C_{N H 4, n o}+C_{N O 2, n o}} \times 100
$$

アナモックス槽の窒素負荷（NLRa: $\mathrm{kg}-\mathrm{N} \cdot \mathrm{m}^{3} \cdot \mathrm{d}^{-1}$ ) は, 次式(3)に示すように, アナモックス槽流入水中のアンモ ニア濃度 $\left(\mathrm{C}_{\mathrm{NH} 4, \mathrm{ai}}: \mathrm{mg}-\mathrm{N} \cdot \mathrm{L}^{-1}\right)$ と亜硝酸濃度 $\left(\mathrm{C}_{\mathrm{NO} 2, \mathrm{ai}}: \mathrm{mg}-\right.$ $\mathrm{N} \cdot \mathrm{L}^{-1}$ ) の和と HRT（Hydraulic Retention Time）（h）から 求めた。

$$
N L R \mathrm{a}=\left(C_{N H 4, \mathrm{ai}}+C_{N O 2, \mathrm{ai}}\right) \times \frac{24}{H R T}
$$

アナモックス槽の処理性能の評価では, 窒素除去速度
（NCR: $\mathrm{kg}-\mathrm{N} \cdot \mathrm{m}^{3} \cdot \mathrm{d}^{-1}$ ) を指標とし，次式(4)に示すように, アナモックス槽流入水中のアンモニア濃度と亜硝酸濃度 の和とアナモックス処理水中のアンモニア濃度 $\left(\mathrm{C}_{\mathrm{NH} 4, \mathrm{ao}}\right.$ : $\left.\mathrm{mg}-\mathrm{N} \cdot \mathrm{L}^{-1}\right)$ と亜硝酸濃度 $\left(\mathrm{C}_{\mathrm{NO} 2, \mathrm{ao}}: \mathrm{mg}-\mathrm{N} \cdot \mathrm{L}^{-1}\right)$ の和およ びHRT（h）から求めた。

$$
N C R=\left\{\left(C_{N H 4, \mathrm{ai}}+C_{N O 2, \mathrm{ai}}\right)-\left(C_{N H 4, \mathrm{ao}}+C_{N O 2, \mathrm{aa}}\right)\right\} \times \frac{24}{H R T}
$$

またアナモックス槽の立上げの指標とした窒素除去 率（RE: \%) は，次式(5)に示すように，アナモックス 槽流入水中のアンモニア濃度, 亜硝酸濃度 $\left(\mathrm{C}_{\mathrm{NO} 2, \mathrm{ai}}\right.$ : $\mathrm{mg}$ $\left.\mathrm{N} \cdot \mathrm{L}^{-1}\right)$ と硝酸濃度 $\left(\mathrm{C}_{\mathrm{NO3}, \mathrm{ai}}: \mathrm{mg} \cdot \mathrm{L}^{-1}\right)$ の和とアナモック ス処理水中のアンモニア濃度, 亜硝酸濃度と硝酸濃度 $\left(\mathrm{C}_{\mathrm{NO} 3, \mathrm{ao}}: \mathrm{mg}-\mathrm{N} \cdot \mathrm{L}^{-1}\right)$ の除去濃度の和から求めた。

$$
R E=\frac{\left(C_{N H 4, \mathrm{ai}}+C_{N O 2, \mathrm{ai}}+C_{N O 3, \mathrm{ai}}\right)-\left(C_{N H 4, \mathrm{ao}}+C_{N O 2, \mathrm{ao}}+C_{N O 3, \mathrm{ao}}\right)}{C_{N H 4, \mathrm{ai}}+C_{N O 2, \mathrm{ai}}+C_{N O 3, \mathrm{ai}}} \times 100
$$

\section{3. 結果および考察}

\section{1 アンモニア製造排水を用いた立上げ性能}

\subsection{BOD 酸化槽}

BOD 酸化槽内の各有機物濃度の変化を図 2 に示す。 運転開始 3 日目以降, 流出の DOC 濃度は低下し, 速や かに有機物処理性能を示した。運転開始 6 日目の原水 DOC およびメタノール濃度はそれぞれ $68,61 \mathrm{mg} \cdot \mathrm{L}^{-1}$ で あったのに対し, BOD 酸化処理水は $14 \mathrm{mg} \cdot \mathrm{L}^{-1}$ および 検出下限 $\left(0.1 \mathrm{mg} \cdot \mathrm{L}^{-1}\right)$ 以下となった。この時点でメ夕 ノールが $1 \mathrm{mg} \cdot \mathrm{L}^{-1}$ 以下となったため, BOD 酸化槽の立 上げが完了したと判断した。その後, 原水 DOC 濃度は $120 \mathrm{mg} \cdot \mathrm{L}^{-1}$ まで大幅に上昇し, BOD 酸化処理水にDOC が残留したが, メタノールは検出されなかった。また 29 日目には工場の運転上の都合により排水の組成が一 部変更された。このため原水 DOC 濃度は $40 \mathrm{mg} \cdot \mathrm{L}^{-1}$ 程 度まで低下し, 有機物のほとんどがメタノールとなった が，安定した有機物処理を維持した。これらの結果によ り, BOD 酸化槽の有機物処理性能は約 1 週間で立上げ を完了し, その後, 安定した処理性能を示すことを明ら かにした。なお排水組成が変更され, DOC 濃度が減少 した 29 日付近より, 亜硝酸の生成が確認され, それ以降, BOD 酸化処理水中の平均覀硝酸濃度は約 $27 \mathrm{mg}-\mathrm{N} \cdot \mathrm{L}^{-1}$ であった。一方で硝酸の生成は確認されなかった。

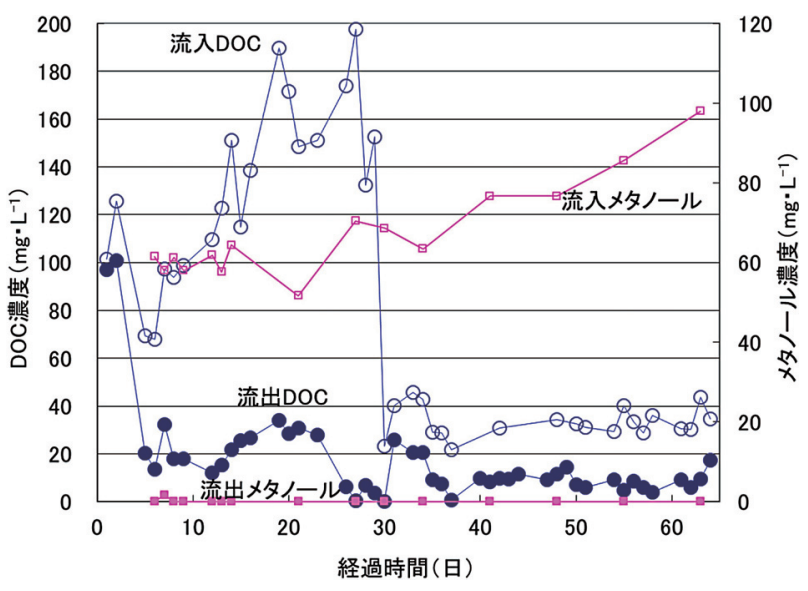

図2 BOD酸化槽の有機物濃度変化 


\subsection{2 亜硝酸型硝化槽}

亜硝酸型硝化槽内の各態窒素濃度の変化を図 3 に示 す。BOD 酸化槽での有機物処理性能が確認されたため, BOD 酸化槽の運転開始 8 日目から BOD 酸化処理水を亜 硝酸型硝化槽へ流入させた。覀硝酸型硝化槽の運転開始 4 日目から, 流出水に亜硝酸が確認され, その濃度は 徐々に上昇した。 8 日目の硝化処理水中の亜硝酸濃度は $300 \mathrm{mg}-\mathrm{N} \cdot \mathrm{L}^{-1}$ となり, 速やかな硝化性能の立ち上がり傾 向を確認した。その後, 原水中の有機物濃度の上昇によ り, 有機物成分が亜硝酸型硝化槽へ流入したため, 硝化 性能は一時的に低下した。しかし有機物濃度の流入が減 少すると硝化性能は速やかに回復した。20日目の処理 水中のアンモニアおよび亜硝酸濃度がそれぞれ $278 \mathrm{mg}$ $\mathrm{N} \cdot \mathrm{L}^{-1}, 316 \mathrm{mg}-\mathrm{N} \cdot \mathrm{L}^{-1}$ となり, 硝化率 $50 \%$ 以上を得るこ とができ, 約 3 週間で亜硝酸型硝化性能の立上げを完了 した。なお,このとき窒素負荷は $1.8 \mathrm{~kg}-\mathrm{N} \cdot \mathrm{m}^{3} \cdot \mathrm{d}^{-1}$ に対し, 硝化速度は $1.0 \mathrm{~kg}-\mathrm{N} \cdot \mathrm{m}^{3} \cdot \mathrm{d}^{-1}$ であった。これらの結果より, 実排水を用いて硝化性能の立上げが可能であることを明 らかにした。その後,BOD 酸化槽で亜硝酸の生成が確認 され, BOD 酸化処理水中に亜硝酸が含有したが, 硝化 処理水中の平均アンモニア, 覀硝酸および硝酸濃度はそ れぞれ $317,332,1 \mathrm{mg}-\mathrm{N} \cdot \mathrm{L}^{-1}$, 硝化率は $51 \%$ となり, 硝 化率制御により，硝化率 50 〜 $60 \%$ に維持できることを 実証した。さらに, 硝酸生成は $1 \mathrm{mg}-\mathrm{N} \cdot \mathrm{L}^{-1}$ 以下とほと んどなく, 安定した亜硝酸型硝化性能を確認した。

Hellinga $~^{25)}$ は亜硝酸型硝化反応の方法として, 高水 温 (30 40 ${ }^{\circ} \mathrm{C}$ ) 条件下で, SRT (Sludge Retention Time) と HRT を制御する SHARON 法を提案している。この 方法においては, HRT が一定に制御されるため, 窒素 負荷は流入アンモニア濃度により決定される。本研究 に用いた約 $700 \mathrm{mg}-\mathrm{N} \cdot \mathrm{L}^{-1}$ のアンモニア濃度の排水を SHARON 法で処理すると仮定すると, 窒素負荷は 0.7 $\mathrm{kg}-\mathrm{N} \cdot \mathrm{m}^{3} \cdot \mathrm{d}^{-1}$ と算出される。また, Tokutomi ら ${ }^{19)}$ は, 半 導体排水を対象にアナモックス反応を用いた窒素処理に ついて報告している。そこで，スポンジ担体を用いて排 水中のアンモニアの約半量を亜硝酸に硝化する工程を 設けており, スポンジ担体の添加率 $20 \%$, 槽内の初期 活性污泥投入量を $2,000 \mathrm{mg} \cdot \mathrm{L}^{-1}$ とし, 処理性能の立上げ を水温 $30^{\circ} \mathrm{C}$ 前後 $\left(26 \sim 35^{\circ} \mathrm{C}\right)$ で検討している。設定さ れている硝化速度は約 $0.4 \mathrm{~kg}-\mathrm{N} \cdot \mathrm{m}^{3} \cdot \mathrm{d}^{-1}$ であり, 後段の アナモックス反応槽の立上げ負荷に合わせる形ではある

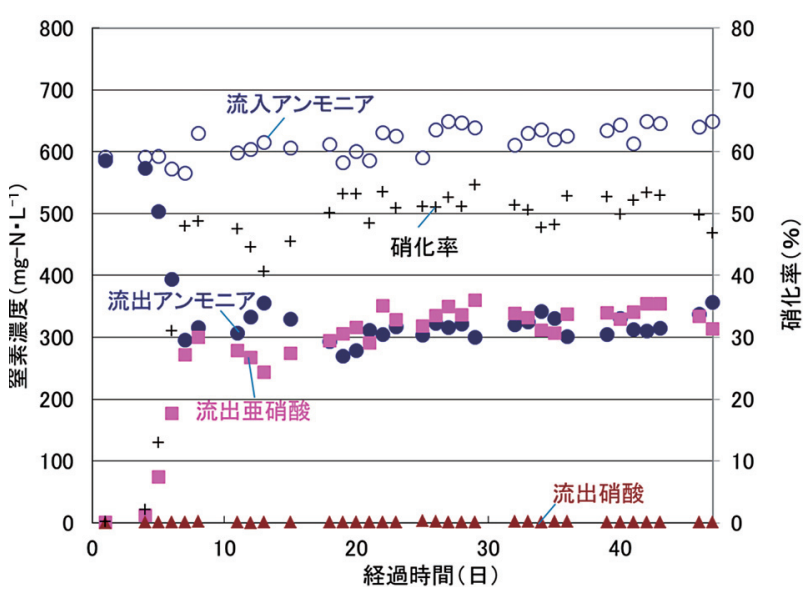

図3 亜硝酸型硝化槽の窒素濃度変化
が，立上げ期間が約 3 ケ月であった。本検討では，担 体添加率 $20 \%$, 初期污泥投入量の換算值としては 4,000 $\mathrm{mg} \cdot \mathrm{L}^{-1}$ であり, この条件で硝化速度 $1.0 \mathrm{~kg}-\mathrm{N} \cdot \mathrm{m}^{3} \cdot \mathrm{d}^{-1}$ を 約 3 週間で得た。初期污泥投入量は多かったが, 包括固 定化担体を用いたことで, HRTによる制約がないこと や硝化菌を多く，安定的に保持できたことから，比較的 短期間での立上げおよび高い処理性能が得られたと考え られる。

本試験期間中では, 硝酸の生成はほとんど確認されな かった。亜硝酸型硝化性能の維持方法として様々報告さ れている $\left.{ }^{25} 27\right)$ 。例えばアンモニア酸化細菌と亜硝酸酸 化細菌の DO の親和性の差を利用し, DO 濃度 $1 \mathrm{mg} \cdot \mathrm{L}^{-1}$ 以下と低くすることで, アンモニア酸化細菌の活性を高 く維持する方法やこれらの細菌の比増殖速度の差を利 用して, 污泥滞留時間 (SRT) を管理することでアンモ ニア酸化細菌を反応槽に維持する方法などがある。また Anthonisen ら ${ }^{26)}$ は遊離アンモニア濃度 $0.1 \sim 10 \mathrm{mg} \cdot \mathrm{L}^{-1}$ で亜硝酸酸化細菌は選択的に阻害を受けると報告してい る。本試験の亜硝酸型硝化槽の DO 濃度は $2 \mathrm{mg} \cdot \mathrm{L}^{-1}$ 以 上を維持している。また包括固定化担体を利用している ためSRT の制御はできない。一方, 本試験の亜硝酸型 硝化槽のアンモニア濃度は約 $150 \sim 300 \mathrm{mg}-\mathrm{N} \cdot \mathrm{L}^{-1}$, 水温 は $15 \sim 30^{\circ} \mathrm{C}$ および $\mathrm{pH} 7.5$ であり, これらより遊離アン モニア濃度は約 $1.5 \sim 9 \mathrm{mg} \cdot \mathrm{L}^{-1}$ と算出できた ${ }^{26)}$ 。したがっ て, 本検討の亜硝酸型硝化槽での硝酸生成の抑制として は, 高濃度の遊離アンモニアが大きく関与していたと考 えられた。

また, 著者らは包括固定化担体を $60^{\circ} \mathrm{C}$ 以上の加熱水 に浸漬させることで带硝酸酸化細菌の活性を抑制する方 法も確立している ${ }^{28)}$ 。もし, 遊離アンモニア濃度が低い 条件となり, 硝酸の生成が顕著となった場合は, これら の方法を用いて, 亜硝酸型硝化性能の維持をすることも できると考える。

\subsection{3 アナモックス槽}

アナモックス槽内の窒素除去速度の変化を図 4 に示 す。アナモックス槽にフェーズ 1 の条件で硝化処理水の 希釈水を通水し，運転を開始した。その結果，アナモッ クス処理水中のアンモニアおよび亜硝酸濃度が徐々に減 少し, アナモックス反応の特徵である硝酸の生成が確 認された。アナモックス槽の運転開始 28 日目には, ア ンモニア，亜硝酸および硝酸濃度はそれぞれ $14,1,9$

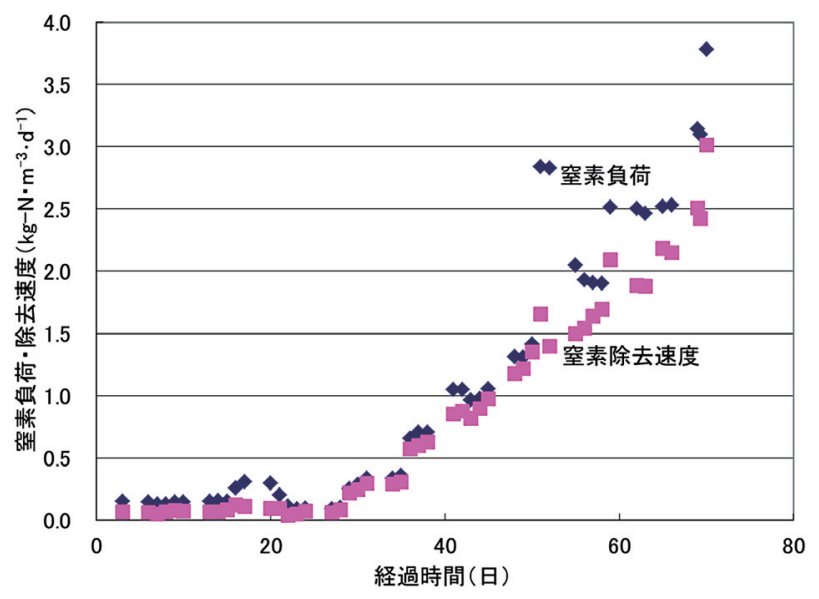

図4 アナモックス槽の窒素除去性能変化 
$\mathrm{mg}-\mathrm{N} \cdot \mathrm{L}^{-1}$ となり，窒素除去率 $76 \%$ を得た。これより， 29 日目から立上げ条件をフェーズ 2 とし, 窒素負荷を 上昇させた結果，30日目に窒素除去率は $79 \%$ となり, 窒素処理性能は速やかに上昇した。36日目にフェーズ 3 とし, 硝化処理水を希釈せず, アナモックス槽に通水 した。この条件においても窒素処理性能は低下しなかっ たため, 段階的に流入量を増やし, 窒素負荷を上昇させ た。その後 41 日目にフェーズ 4, 48 日目にフェーズ 5 , 55 日目にフェーズ 6 ，59日目にフェーズ 7 と徐々に窒 素負荷を上げることができ, 70 日目に最終のフェーズ 8 に到達した。このとき, 窒素負荷 $3.8 \mathrm{~kg}-\mathrm{N} \cdot \mathrm{m}^{3} \cdot \mathrm{d}^{-1}$ に 対し, 窒素除去速度は $3.0 \mathrm{~kg}-\mathrm{N} \cdot \mathrm{m}^{3} \cdot \mathrm{d}^{-1}$ となり, 立上げ を完了した。これらの結果から, 実排水を用いてアナモッ クス槽は約 2 ケ月で立上がることを明らかにした。消化 污泥脱水ろ液を対象とした場合でも, Van de Star ら ${ }^{15)}$ は グラニュールを用いたアナモックス反応の立上げにおい て, グラニュールの流出や阻害影響などがあり, アナモッ クスグラニュールを追加投入しながら, 所定の処理性能 を得るまでに 3 年半を費やしている。一方で Tokutomi ら ${ }^{19)}$ は，グラニュールを用いたアナモックス反応の立上 げにおいて，半導体排水を対象に検討を行っている。ア ナモックス槽へは, 嫌気グラニュールを槽容積に対して $25 \%$ 程度投入し，初期アナモックスグラニュール投入 量は, 槽内に対して, $1,800 \mathrm{mg}-\mathrm{SS} \cdot \mathrm{L}^{-1}$ としている。ま た運転 1 カ月後に, 嫌気グラニュールを槽容積に対して $25 \%$ 程度投入し，アナモックスグラニュールを $600 \mathrm{mg}$ $\mathrm{SS} \cdot \mathrm{L}^{-1}$ 相当投入している。その結果, 約 3 ケ月で窒素 除去速度約 $3 \mathrm{~kg}-\mathrm{N} \cdot \mathrm{m}^{3} \cdot \mathrm{d}^{-1}$ を得たと報告している。本検 討では，包括固定化担体として槽内に担体を $20 \%$ 投入 し, その中の初期のアナモックス污泥量の換算值として は $400 \mathrm{mg}-\mathrm{SS} \cdot \mathrm{L}^{-1}$ である。そして適宜窒素濃度と負荷を 調整することで, 窒素除去速度 $3.0 \mathrm{~kg}-\mathrm{N} \cdot \mathrm{m}^{3} \cdot \mathrm{d}^{-1}$ を約 2 ケ 月で得ている。またこの間，アナモックス担体や污泥な どを補給することはなかったため, 初期アナモックス投 入量が比較的少ない条件で, 安定的に立上げができたと 考える。

\section{1.4 前脱窒槽}

前脱窒槽内の各態窒素濃度の変化を図 5 に示す。原 水を約 $30 \mathrm{~m}^{3} \cdot \mathrm{d}^{-1}$, 亜硝酸型硝化槽からの循環水を約 4 $\mathrm{m}^{3} \cdot \mathrm{d}^{-1}$ の条件で前脱窒槽に流入させた。その結果, 速や かに循環水由来の亜硝酸と原水由来の DOC は同時に除

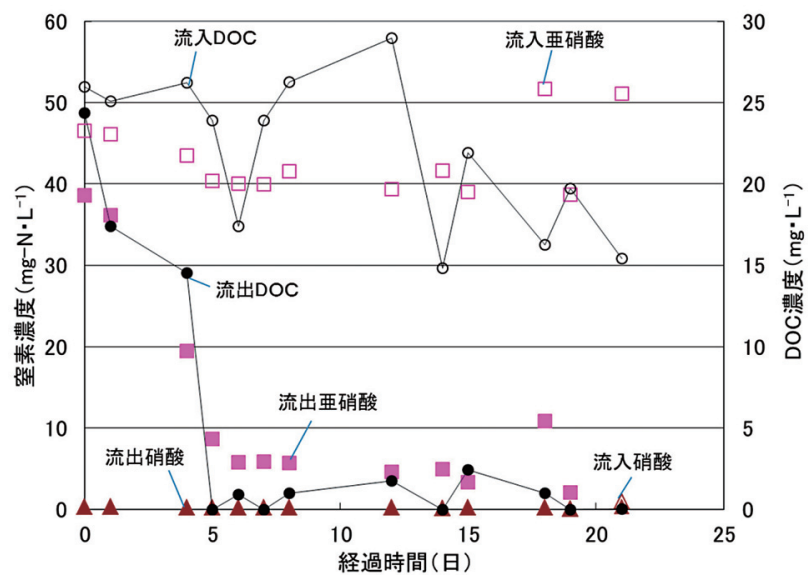

図5＼cjkstart前脱窒槽の窒素およびDOC濃度変化
去されはじめた。前脱窒槽の運転開始 5 日目にはDOC 濃度が $1 \mathrm{mg} \cdot \mathrm{L}^{-1}$ 以下, 亜硝酸濃度も $9 \mathrm{mg}-\mathrm{N} \cdot \mathrm{L}^{-1}$ となり, 立上げを完了した。その後, DOC 濃度は $2 \mathrm{mg} \cdot \mathrm{L}^{-1}$ 以下, 亜硝酸濃度は概ね $10 \mathrm{mg}-\mathrm{N} \cdot \mathrm{L}^{-1}$ 以下となり, 覀硝酸型硝 化槽からの循環水中の亜硝酸を利用した脱窒性能を確認 した。

著者らは包括固定化した脱窒担体について, メタノー ルを水素供与態とし，模擬排水を用いた脱窒処理性能の 立上げ検討を水温 $30^{\circ} \mathrm{C}$ 条件で行っており, 約 1 週間で 脱窒性能の立ち上がり傾向を確認し, 約 2 週間で脱窒速 度 $4 \mathrm{~kg}-\mathrm{N} \cdot \mathrm{m}^{3} \cdot \mathrm{d}^{-1}$ を得ている ${ }^{29)}$ 。今回の立上げを完了し た時点の脱窒速度は約 $0.1 \mathrm{~kg}-\mathrm{N} \cdot \mathrm{m}^{3} \cdot \mathrm{d}^{-1}$ であり, 模擬排 水を用いた試験と同等の立上げ傾向を得ており, 包括固 定化した脱窒担体においても, 実排水を用いて速やかな 立上げおよび安定した処理性能を得られることがわかっ た。

これらの結果より，メタノールを含有するアンモニア 製造排水において，メタノールを適切に前処理すること で，短期間で窒素処理工程を立上げられることを明らか にし，本システム全体の立上げに成功した。

\section{2 尿素排水を用いた低水温条件での窒素処理性能}

\section{2.1 亜硝酸型硝化槽}

高水温のアンモニア製造排水が停止したため, 常温の 尿素排水を用いて運転を行った。亜硝酸型硝化槽内の各 態窒素濃度と水温の変化を図 6 に示す。BOD 酸化処理 水を亜硝酸型硝化槽に $17 \mathrm{~m}^{3} \cdot \mathrm{d}^{-1}$ で通水した。その結果, 平均水温 $16.5^{\circ} \mathrm{C}\left(15.1 \sim 19.3^{\circ} \mathrm{C}\right)$ と低水温条件下におい ても硝化処理水の平均アンモニアおよび带硝酸濃度はそ れぞれ $181,268 \mathrm{mg}-\mathrm{N} \cdot \mathrm{L}^{-1}$ となり, 硝化率 $60 \%$ を得た。 また硝酸の生成はなく, 低水温条件下で安定した带硝酸 型の硝化処理性能を確認した。なお, このとき平均窒素 負荷は $0.7 \mathrm{~kg}-\mathrm{N} \cdot \mathrm{m}^{3} \cdot \mathrm{d}^{-1}$ に対し, 平均硝化速度は $0.4 \mathrm{~kg}$ $\mathrm{N} \cdot \mathrm{m}^{3} \cdot \mathrm{d}^{-1}$ であった。

\subsection{2 アナモックス槽}

アナモックス槽での窒素処理性能と水温の変化を図 7 に示す。硝化処理水を $15 \mathrm{~m}^{3} \cdot \mathrm{d}^{-1}$ で直接アナモック ス槽に通水した。その結果, 平均水温 $16.1^{\circ} \mathrm{C}$ （14.8～ $\left.18.8^{\circ} \mathrm{C}\right)$ の条件で, アナモックス処理水の平均アンモニ ア, 悪硝酸および硝酸濃度はそれぞれ，20，15，50 mg$\mathrm{N} \cdot \mathrm{L}^{-1}$ となり, 平均窒素除去率は $81 \%$ であった。このと きの平均窒素負荷 $1.3 \mathrm{~kg}-\mathrm{N} \cdot \mathrm{m}^{3} \cdot \mathrm{d}^{-1}$ に対し, 平均窒素除

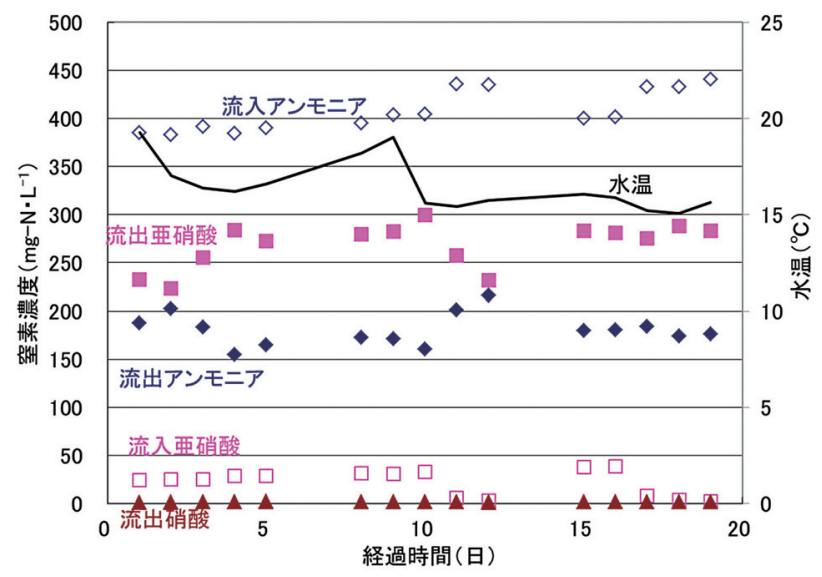

図6＼cjkstart亜硝酸型硝化槽での窒素濃度と水温変化 
去速度は $1.2 \mathrm{~kg}-\mathrm{N} \cdot \mathrm{m}^{3} \cdot \mathrm{d}^{-1}$ を得, 低水温条件下での所定 の窒素処理性能を得ることができた。

尿素成分を主体とする排水中のアンモニアを亜硝酸型 硝化反応およびアナモックス反応を利用して低水温条件 下で窒素処理した報告例はほとんどない。尿素は比較的 容易に加水分解され，アンモニア態の窒素が残留する。 また各処理工程においても後段になるにつれ, アンモニ アの濃度は増加する傾向にあった。亜硝酸型硝化槽では 硝化率 $60 \%$ 程度と高かったため, 式(1)によると, アナ モックス槽でアンモニアの残留量は亜硝酸の残留量に比 べ低くなる可能性がある。しかしながら実際, アナモッ クス槽でのアンモニアの残留は亜硝酸濃度と同程度で あった。これはアナモックス槽において尿素が分解され アンモニアが一部生成していたものと考えられる。ま た，今回の尿素排水中のアンモニアの割合は全窒素中の $30 \%$ 程度であったが，特に尿素成分による亜硝酸型硝化 反応およびアナモックス反応への阻害影響はみられな かった。なお，本検討では尿素排水中に含まれるアンモ ニア成分のみの処理を実施した。残留する尿素成分を処 理する場合には, 物理化学的または生物学的に尿素をア ンモニアに加水分解する前処理プロセスが必要である。

これらの結果から, 化学工場系の尿素排水を対象に, 低水温条件 $\left(15 \sim 20^{\circ} \mathrm{C}\right)$ での排水処理試験を行い, 低 水温条件でもアナモックス処理システムを適用できる見 通しを得た。

\section{3 水温変動条件での窒素処理性能}

\section{3.1 原水切り替えによる水温変動試験}

\section{(1) 亜硝酸型硝化槽}

亜硝酸型硝化槽での各態窒素濃度と水温の変化を図 8 に示す。BOD 酸化処理水を $37 \mathrm{~m}^{3} \cdot \mathrm{d}^{-1}$ で带硝酸型硝化槽 に通水し, 平均窒素負荷 0.7 から $2.4 \mathrm{~kg}-\mathrm{N} \cdot \mathrm{m}^{3} \cdot \mathrm{d}^{-1}$ まで上 昇させた。原水を尿素排水からアンモニア製造排水に切 替え， 5 日目（24 日）には水温が $28.8^{\circ} \mathrm{C}$ まで昇した。 硝化処理水のアンモニアおよび带硝酸濃度はそれぞれ $302,382 \mathrm{mg}-\mathrm{N} \cdot \mathrm{L}^{-1}$ となり, 硝化率 $56 \%$ を得た。上記の とおり, 水温を上昇させ, 窒素負荷を急激に上げた場合 でも, 硝化処理性能は速やかに追従し, また硝化率につ いても制御できることがわかった。

(2) アナモックス槽

アナモックス槽での窒素処理性能と水温の変化を図 9 に示す。原水切替え 2 日目（21日）までは硝化処理水

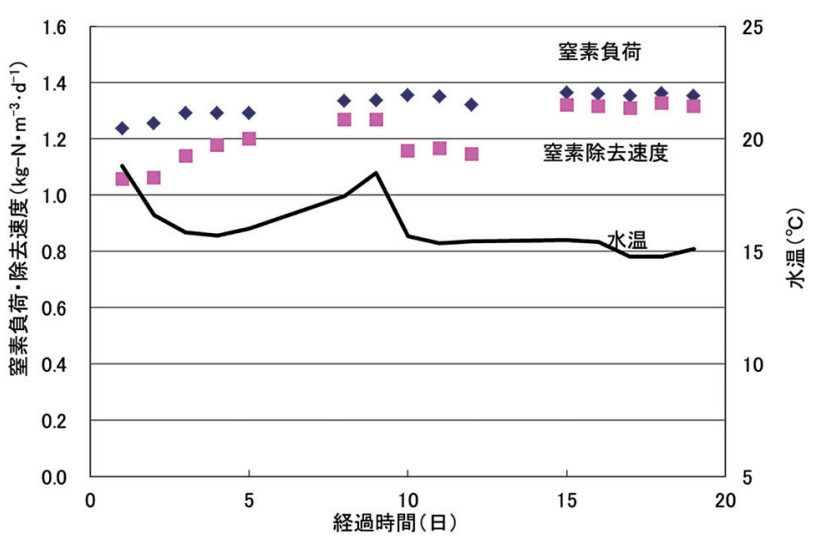

図7 アナモックス槽での窒素除去性能と水温変化
を約 $15 \mathrm{~m}^{3} \cdot \mathrm{d}^{-1}$ で通水し, その後, $33 \mathrm{~m}^{3} \cdot \mathrm{d}^{-1}$ で通水した。 切替え 3 日目 $\left(22\right.$ 日）には水温が $28.7^{\circ} \mathrm{C}$ に上昇し, 窒 素負荷 $4.1 \mathrm{~kg}-\mathrm{N} \cdot \mathrm{m}^{3} \cdot \mathrm{d}^{-1}$ に対し, 窒素除去速度は $3.2 \mathrm{~kg}-$ $\mathrm{N} \cdot \mathrm{m}^{3} \cdot \mathrm{d}^{-1}$ となり, 設定值以上の性能を確認した。6 日

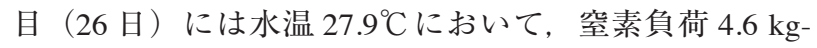
$\mathrm{N} \cdot \mathrm{m}^{3} \cdot \mathrm{d}^{-1}$ に対し, 窒素除去速度 $4.2 \mathrm{~kg}-\mathrm{N} \cdot \mathrm{m}^{3} \cdot \mathrm{d}^{-1}$ を得, 水温を上昇させ, 急激に窒素負荷を上げた場合でも速や かに処理性能は追従することがわかった。

これらより排水の種類が変更され, 水温や窒素負荷が 変動する条件においても, アナモックス処理システムは 速やかに対応でき，産業排水処理に適用できる見通しを 得た。

\section{3.2 アンモニア製造排水での水温変動試験 \\ (1) 亜硝酸型硝化槽}

原水の水温を $20{ }^{\circ} \mathrm{C}$ 付近とし, BOD 酸化処理水を 17 $\mathrm{m}^{3} \cdot \mathrm{d}^{-1}$ で亜硝酸型硝化槽に通水した。その結果を引き続 き図 8 に示す。水温変更 4 日目（29日）には, 覀硝酸 型硝化槽の水温が $20^{\circ} \mathrm{C}$ 以下となった。このとき曝気風 量の調整不具合により硝化率は一時的に低下したもの の, 低水温条件下においても亜硝酸の生成が確認された。 水温が $20^{\circ} \mathrm{C}$ 以下となった 12 日間の平均水温は $17.6{ }^{\circ} \mathrm{C}$ $\left(16.5 \sim 19.5^{\circ} \mathrm{C}\right)$ であり，このとき平均窒素負荷 $1.2 \mathrm{~kg}$ $\mathrm{N} \cdot \mathrm{m}^{3} \cdot \mathrm{d}^{-1}$ であった。硝化処理水の平均アンモニアおよ び亜硝酸濃度はそれぞれ $295,396 \mathrm{mg}-\mathrm{N} \cdot \mathrm{L}^{-1}$ を得, 設定 值である硝化率 $50 \%$ 以上を確認した。BOD 酸化槽で徐々 に亜硝酸が生成され, 流入水中の亜硝酸濃度は変動した が, 硝化率制御により, 安定した硝化率を得た。また硝 酸の生成はなかった。なおこのときの亜硝酸型硝化槽の 平均硝化速度は, 尿素排水を用いた試験時と同等であっ た。これらの結果から, 高水温から低水温にした場合で も迅速な対応ができ, 低水温条件下で安定した亜硝酸型 硝化処理性能を確認した。

\section{(2) アナモックス槽}

水温低下によるアナモックス槽の窒素処理性能の変化 を引き続き図 9 に示す。原水の水温を低下させ 4 日目 (29 日）にはアナモックス槽内の水温が $20^{\circ} \mathrm{C}$ 以下となった。 亜硝酸型硝化槽の硝化率変動により一時的に窒素除去率 は低下したが, 29 日目以降の平均水温 $17.1^{\circ} \mathrm{C} （ 16.0$ $19.2^{\circ} \mathrm{C}$ ）において, 窒素負荷 $2.1 \mathrm{~kg}-\mathrm{N} \cdot \mathrm{m}^{3} \cdot \mathrm{d}^{-1}$ に対し, 窒 素除去速度は $1.9 \mathrm{~kg}-\mathrm{N} \cdot \mathrm{m}^{3} \cdot \mathrm{d}^{-1}$, 平均窒素除去率 $83 \%$ を 得た。

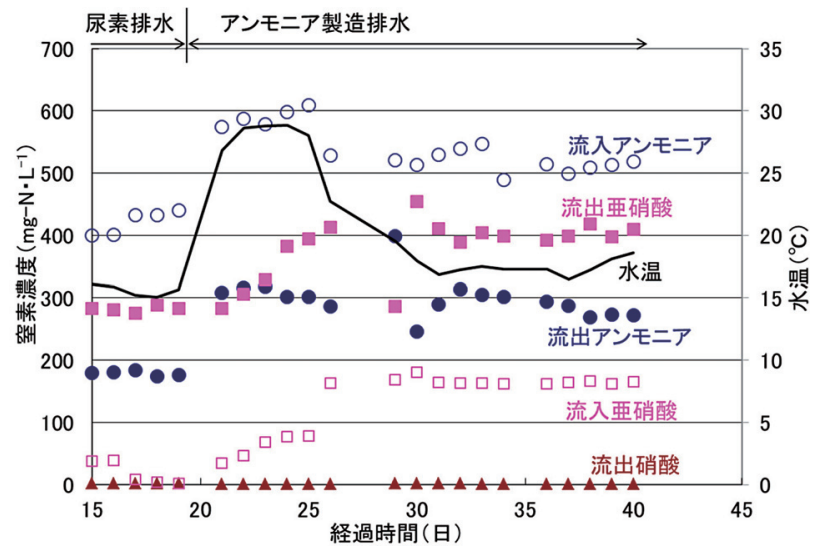

図8 亜硝酸型硝化槽での窒素濃度と水温変化 


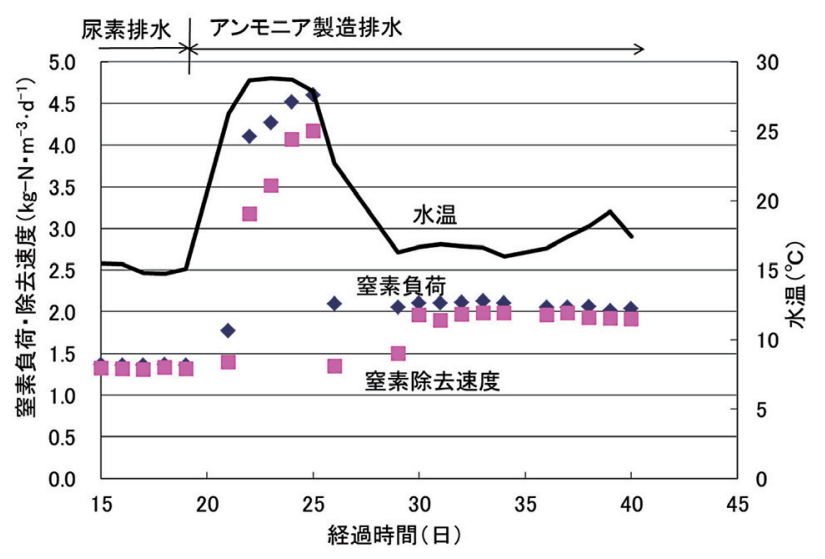

図9 アナモックス槽での窒素除去性能と水温変化

これらの結果より，水温および窒素負荷の急激な変動 に対しても，それぞれの条件で窒素処理性能は速やかに 追従し，大きな影響が生じないことを確認した。さらに アンモニア製造排水を用いた低水温試験においても設定 值を十分満足する高い窒素処理性能を得た。

これらの結果により，化学工場系から排出される有機 物を含むアンモニア製造排水に対し，低水温条件におい て，亜硝酸型硝化およびアナモックス槽により高い窒素 除去性能を安定して得ることができることが示された。

水温 $15 \sim 20^{\circ} \mathrm{C}$ の低水温条件において，亜硝酸型硝化 反応およびアナモックス反応を実排水で検討した例は少 ない。さらには水温が $15^{\circ} \mathrm{C}$ から $30^{\circ} \mathrm{C}$ の範囲で変動し, 窒素負荷を 3 倍程度変動させた試験例もない。これら包 括固定化担体を用いたことで，固定化された硝化菌やア ナモックス菌は担体内に高密度に維持されていたこと で，急激な水温や窒素負荷変動に対して影響が少なく性 能を維持することができたと考えられる。

著者らは包括固定化したアナモックス担体を用いて, 水温変動の検討を連続試験条件下で，合成排水を用いて 行っている ${ }^{12)}$ 。この結果では，水温 $32^{\circ} \mathrm{C}$ から $22^{\circ} \mathrm{C}$ に低 下させると，アナモックス反応の温度依存性により，窒 素除去速度は $6.2 \mathrm{~kg}-\mathrm{N} \cdot \mathrm{m}^{3} \cdot \mathrm{d}^{-1}$ から $2.8 \mathrm{~kg}-\mathrm{N} \cdot \mathrm{m}^{3} \cdot \mathrm{d}^{-1}$ まで 約 $55 \%$ 低下している。本検討においては, 水温 $27.9^{\circ} \mathrm{C}$ から $17.1{ }^{\circ} \mathrm{C} へ の$ 低減により, 窒素除去速度は $4.2 \mathrm{~kg}$ $\mathrm{N} \cdot \mathrm{m}^{3} \cdot \mathrm{d}^{-1}$ から $1.9 \mathrm{~kg}-\mathrm{N} \cdot \mathrm{m}^{3} \cdot \mathrm{d}^{-1}$ まで約 $55 \%$ 低下し，温度 依存性は概ね同等の傾向を得ていた。生産内容の変更や 定期修繕などにより，排水種類が変動し，水温の急激な 変動がある場合, 本試験条件の水温約 $30^{\circ} \mathrm{C}$ から $20^{\circ} \mathrm{C}$ の 低下については，窒素負荷を $55 \%$ 低減させることで対 応可能であると考えられる。

\section{4. まとめ}

包括固定化担体を用いたアナモックス処理システム を産業排水に適用することを目的に，アナモックス槽 5 $\mathrm{m}^{3}$ 規模の実証試験装置を用いて, 化学工場系の実排水 を対象に，産業排水の適用で必要とされる運転要素の実 証試験を行った。この結果，大幅な水温変動や排水種類 の変動に対応でき，低水温条件下においても産業排水処 理に本システムが適用できることを実証した。この研究 から得られた主な結果を以下に示す。

1）メタノールを含有するアンモニア製造排水におい
て, メタノールを適切に前処理することで, 水温 $30^{\circ} \mathrm{C}$ の条件で, 亜硝酸型硝化性能は約 3 週間, アナモックス 性能は約 2 ヶ月，で立上がり，実排水を用いてシステム 全体の立上げに成功した。

2）原水がアンモニア製造排水から尿素排水に変更さ れ, 低水温条件 $\left(15 \sim 20^{\circ} \mathrm{C}\right)$ で排水処理試験を行った 結果，アナモックス槽は平均水温 $16.1^{\circ} \mathrm{C}$ の条件で窒素除 去速度 $1.2 \mathrm{~kg}-\mathrm{N} \cdot \mathrm{m}^{3} \cdot \mathrm{d}^{-1}$ を得, 低水温条件でも安定した 処理性能を確認した。

3）再度, 尿素排水からアンモニア製造排水に変更さ れ，水温約 $30^{\circ} \mathrm{C}$ 一上昇させた結果，アナモックス槽で は 3 日以内に高水温時での窒素除去速度である $4.2 \mathrm{~kg}$ $\mathrm{N} \cdot \mathrm{m}^{3} \cdot \mathrm{d}^{-1}$ 以上を得, 水温打よび窒素負荷変動に速やか 対応でき，産業排水処理に適用できる見通しを得た。

4）アンモニア製造排水を用いて低水温条件下での処

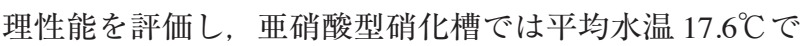
硝化率 $56 \%$ の処理水質を得, アナモックス槽では平均水 温 $17.1^{\circ} \mathrm{C}$ で窒素除去速度 $1.9 \mathrm{~kg}-\mathrm{N} \cdot \mathrm{m}^{3} \cdot \mathrm{d}^{-1}$ を得, 低水温条 件の産業排水処理においても適用できる見通しを得た。

\section{謝 辞}

この成果は, 独立行政法人新エネルギー・産業技術総 合開発機構 (NEDO) の委託業務にて得られたものである。 （原稿受付 2015 年 1 月 23 日) （原稿受理 2015 年 5 月 18 日）

\section{参 考 文 献}

1 ) 環境省 (2011) 化学的酸素要求量, 窒素含有量及びりん含有量 に係る総量削減基本方針, https://www.env.go.jp/water/heisa/7kisei/ sakugen_houshin.pdf（2015 年 1 月時点）

2 ) 浅野昌道, 水谷洋, 中村謙治 (2005) 電解による廃水中窒素分 解システム, 三菱重工技報, 42, 180-183.

3 ）古川憲治 (2014) アナモックスに関する情報公開, 水環境学会 誌, 37 (A), 315.

4 ) Mulder, A., van de Graaf, A. A., Robertson, L. A. and Kuenen, J. G. (1995) Anaerobic ammonium oxidation discovered in a denitrifying fluidized bed reactor, FEMS Microbiol. Ecol., 16, 177-184.

5 ) van de Graaf, A. A., de Bruijn, P., Robertson, L. A., Jetten, M. S. M. and Kuenen, J. G. (1996) Autotrophic growth of anaerobic ammonium-oxidizing microorganisms in a fluidized bed reactor, Microbiol., 142, 2187-2196.

6 ) Strous, M., Fuerst, J. A., Kramer, E. H. M., Logemann S., Muyzer G., van de Pas-Schoonen, K. T., Webb, R., Kuenen, J. G. and Jetten, M. S. M. (1999) Missing lithotroph identified as new planctomycete, Nature, 400, 446-449.

7 ) Strous, M., Heijnen, J. J., Kuenen, J. G. and Jetten, M. S. M. (1998) The sequencing batch reactor as a powerful tool for the study of slowly growing anaerobic ammonium-oxidation microorganisms, Appl. Microbiol. Biotechnol., 50, 589-596.

8 ）井坂和一 (2004) 嫌気性アンモニア酸化法の有効性と実用化に 向けた課題と対策, 水環境学会誌, 27, 458-462.

9 ) Tsushima, I., Ogasawara, Y., Kindaichi, T., Satoh, H. and Okabe, S. (2007) Development of high-rate anaerobic ammonium-oxidizing (anammox) biofilm reactors, Water Res., 41, 1623-1634.

10) Isaka, K., Date, Y., Sumino, T. and Tsuneda, S. (2007) Ammonium removal performance of anaerobic ammonium-oxidizing bacteria immobilized in polyethylene glycol gel carrier, Appl. Microbiol. Biotechnol., 76, 1457-1495.

11) Strous, M., Heijnen, J. J., Kuenen, J. G. and Jetten, M. S. M. (1999) Key physiology of anaerobic ammonium oxidation, Appl. Environ. Microbiol., 65, 3248-3250.

12) Isaka, K., Kimura, Y., Sumino, T. and Tsuneda, S. (2008) Nitrogen removal performance using anaerobic ammonium oxidation at low 
temperatures, FEMS microbiology letters, 282 (1) , 32-38.

13) Strous, M., Van Gerven, E., Zheng, P., Kuenen, J. G. and Jetten, M. S. M. (1997) Ammonium removal from concentrated waste streams with the anaerobic ammonium oxidation (ANAMMOX) process in different reactor configurations, Water Res., 31, 1955-1962.

14) Furukawa, K., Rouse, J. D., Bhatti, Z. I., Imajo, U., Nakamura, K. and Ishida, H. (2002) Characterization of microbial community in an anaerobic ammonium-oxidizing biofilm cultured on a nonwoven biomass carrier. J. Biosci. Bioeng., 94, 87-94.

15) Van de Star, W. R. L., Adma, E. R., Blommers, D., Mulder, J. W., Tokutomi, T., Strous, M., Picioreanu, C. and van Loosderecht, M. S. M. (2007) Startup of reactors for anoxic ammonium oxidation: Experience from the first full-scale anammox reactor in Rotterdam, Water Res., 41, 4149-4163.

16) Lackner, S., Gilbert, E. M., Vlaeminck, S. E., Joss, A., Horn, H. and van Loosdrecht, M. C. M. (2014) Full-scale partial nitritation/ anammox experiences -an application survey, Water Res., 55, 292303.

17) Isaka, K., Itokawa, H., Kimura, Y., Noto, K. and Murakami, T. (2011) Novel autotrophic nitrogen removal system using gel entrapment technology, Bioresour. Technol., 102, 7720-7726.

18) Kimura, Y., Itokawa, H., Noto, K., Murakami, T. and Isaka, K. (2013) Stability of autotrophic nitrogen removal system under four non-steady operations, Bioresour. Technol., 137, 196-201.

19) Tokutomi, T., Yamauchi, H., Nishimura, S., Yoda, M. and Abma, W. (2011) Application of the nitritation and anammox process into inorganic nitrogenous wastewater from semiconductor factory, $J$. Environ. Engin., 137 (2) , 146-154.

20) Sumino, T., Nakamura, H., Mori, N. and Kawaguchi, Y. (1992) Immobilization of nitrifying bacteria by polyethylene glycol prepolymer, J. Ferment. Bioengin., 73 (1) , 37-42.
21) Oslislo, A. and Lewandowski, Z. (1985) Inhibition of nitrification in the packed bed reactors by selected organic compounds, Water Res., 19 (4) , 423-426.

22) Guven, D., Depana, A., Kartal, B., Schamid, M. C., Maas, B., van de Pas-Schoonen, K., Sozen, S., Mendez, R., Op den Camp, H. J. M., Jetten, M. S. M., Strous, M. and Schmidt, I. (2005) Propionate oxidation by and methanol inhibition of anaerobic ammoniumoxidizing bacteria, Appl. Environ. Microbiol., 71, 1066-1071.

23) Isaka, K., Suwa, Y., Kimura, Y., Yamagishi, T., Sumino, T. and Tsuneda, S. (2008) Anaerobic ammonium oxidation (anammox) irreversibly inhibited by methanol, Appl. Microbiol. Biotechnol., 81, 379-385.

24) Kimura, Y., Isaka, K., Kazama, F. and Sumino, T. (2010) Effects of nitrite inhibition on anaerobic ammonium oxidation, Appl. Microbiol. Biotechnol., 86, 359-365.

25) Hellinga, C., Schellen, A. A. J. C., Mulder, J. W., Van Loosdrecht, M. C. M. and Heijnen, J. J. (1998) The Sharon process: An innovative method for nitrogen removal from ammonium-rich waste water, Water Sci. Technol., 37, 135-142.

26) Anthonisen, A. C., Loehr, R. C., Prakasam, T. B. S. and Srinath, E. G. (1976) Inhibition of nitrification by ammonia and nitrous acid, $J$. Water Pollut. Control Fed., 48 (5) , 835-852.

27) Yang, J., Zhang, L., Daisuke, H., Takahiro, S., Ma, Y., Li, Z. and Furukawa, K. (2010) High rate partial nitrification treatment of reject wastewater, J. Biosci. Bioengin., 110 (4) , 436-440.

28) Isaka, K., Sumino, T. and Tsuneda, S. (2008) Novel nitritation process using heat-shocked nitrifying bacteria entrapped in gel carriers, Process Biochemistry, 43 (3) , 265-270.

29) Isaka, K., Kimura, Y., Osaka, T. and Tsuneda, S. (2012) Highrate denitrification using polyethylene glycol gel carriers entrapping heterotrophic denitrifying bacteria, Water Res., 46 (16) , 4941-4948.

\section{[論 文 要 旨]}

包括固定化したアナモックス担体と反応槽容積 $5 \mathrm{~m}^{3}$ 規模のアナモックス槽を用い, 前処理プロセスと組 み合わせ，化学工場排水中の窒素除去の実証試験を行った。高水温のアンモニア製造排水を用いて，水温 $30^{\circ} \mathrm{C}$ 条件で処理性能の立上げを行った結果, アナモックス槽は約 2 ケ月で所定の処理性能を得た。その後,

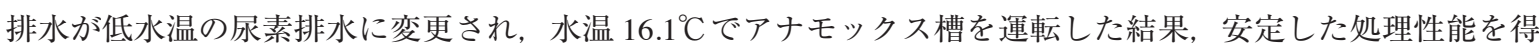
た。再度，アンモニア製造排水に切替わり，水温を約 $30^{\circ} \mathrm{C} に 上$ 昇させたが，アナモックス槽は 3 日以内で 所定の窒素除去速度まで上昇した。次に，水温 $17.1^{\circ} \mathrm{C}$ の低水温条件下で運転した結果，安定して窒素除去速 度 $1.9 \mathrm{~kg}-\mathrm{N} \cdot \mathrm{m}^{3} \cdot \mathrm{d}^{-1}$ を得た。包括固定化アナモックス担体を用いた本システムは, 産業排水処理で求められ る大幅な水温変動や排水種類の変動に対応でき,さらに低水温条件下においても適用できることを実証した。

キーワード : アンモニア ; 包括固定化担体 ; アナモックス ; 生物学的排水処理 ; 化学工場排水 